\title{
Biochemical Test and Isolation of Antimicrobial Activity From Extract of Starfruit seeds (Averrhoa carambola.L)
}

\author{
Habibi Hidayat \\ Program Studi Kimia \\ Fakultas Matematika dan Ilmu Pengetahuan Alam \\ Universitas Islam Indonesia, Yogyakarta, Indonesia \\ E-mail : 156120210@uii.ac.id
}

\begin{abstract}
ABSTRAK
Telah dilakukan penelitian tentang uji biokimia dan aktivitas antimikroba dari isolasi ekstrak biji buah belimbing (Averrhoa carambola.L). Penelitian ini bertujuan untuk mengetahui bagaimana uji biokimia dan aktivitas antimikroba, serta proses isolasi dari ekstrak biji buah Belimbing (Averrhoa carambola.L). Dari hasil penelitian yang telah dilakukan diperoleh hasil untuk sampel ekstrak biji buah Belimbing (Averrhoa carambola.L) yaitu BB 36 dan BB 48 memiliki jumlah koloni yaitu 110. 10 $\mathrm{cfu} / \mathrm{ml}$ dan $126.10^{7} \mathrm{cfu} / \mathrm{ml}$. Sehingga dapat digunakan sebagai bahan pangan untuk probiotik. Sampel BB 36 dan BB 48 memiliki bentuk morfologi seperti basil (batang) dan merupakan jenis bakteri Gram positif. sampel BB 36 dan BB 48 memiliki resistensi terhadap asam yang cukup baik karena dapat hidup pada pH 2.0 - 6.0. untuk uji aktivitas antimikroba dari sampel BB 36 memiliki zona bening yang lebih luas yaitu pada hari pertama sampai ketiga terus meningkat yaitu sebesar $12 \mathrm{~mm}, 14 \mathrm{~mm}$ dan 16 mm. Sedangkan sampel BB 48 memiliki zona bening yang cukup baik jika dibandingkan dengan antibiotik ampisilin yaitu sebesar $10 \mathrm{~mm}, 12 \mathrm{~mm}$ dan $14 \mathrm{~mm}$.
\end{abstract}

Kata Kunci : Uji biokimia, aktivitas antimikroba, ekstrak biji, buah belimbing

\begin{abstract}
The research has been done for the biochemical test and isolation of antimicrobial activity from seeds starfruit extract ((Averrhoa carambola.L). This research aimed to found out how biochemical test, antimicrobial activity and the isolation process from extract of starfruit seeds (Averrhoa carambola.L). From the research that has been done shows to sample extract of starfruit seeds (Averrhoa carambola.L) that $B B 36$ and $B B 48$ have a number of colonies, namely $110.10^{7} \mathrm{cfu} / \mathrm{mL}$ and $126.10^{7} \mathrm{cfu} / \mathrm{mL}$. So that, it can be used as food for probiotics. The samples $B B 36$ and $B B 48$ have a morphology type is bacillus and Gram-positive bacteria. It has resistance to acids was very good because it can live at $\mathrm{pH} 2.0$ - 6.0. to test the antimicrobial activity of the sample BB 36 has a wider clear zone is on the first day until the third continues to increase is equal to $12 \mathrm{~mm}, 14 \mathrm{~mm}$ and $16 \mathrm{~mm}$ while the sample $B B 48$ has a clear zone is quite good when compared to the antibiotic ampicillin to $10 \mathrm{~mm}, 12 \mathrm{~mm}$ and $14 \mathrm{~mm}$.
\end{abstract}

Key Words: Biochemical test, antimicrobial activity, seed extract, star fruit

\section{Pendahuluan} Indonesia merupakan negara yang

kaya akan sumber daya alam dan tanaman obat. Berbagai jenis tumbuhan yang ditanam di negara ini dapat hidup dengan subur dan beragam. Hal ini disebabkan karena iklimnya 
yang tropis dan kondisi tanah yang mendukung, memberikan kesempatan emas bagi masyarakat Indonesia untuk hidup sehat dan sejahtera. Kesehatan merupakan salah satu hal terpenting yang harus terpenuhi dalam kehidupan seseorang. Karena sehat merupakan suatu keadaan dimana seorang individu tidak terkena penyakit atau dalam kondisi baik, artinya seorang individu itu memperoleh keadaan yang sejahtera baik dari badan, jiwa, dan kehidupan sosial. Selain itu, makna kesehatan menurut World Health Organization (WHO) sehat adalah suatu keadaan kondisi fisik, mental, dan kesejahteraan sosial yang merupakan satu kesatuan dan bukan hanya bebas dari penyakit atau kecacatan.

Banyak masyarakat yang masih mengalami sakit karena kondisi cuaca yang sering berubah-ubah tanpa kompromi, terutama penyakit-penyakit yang berhubungan dengan kondisi fisik manusia. Seperti demam, batuk, flu, dan sakit tenggorokan atau radang. Penyakit ini cukup ringan dan kesannya sepele, tetapi ini cukup menganggu aktivitas kerja manusia dalam kehidupan sehari-hari. Terutama jika penyakit ini sampai menyerang anak-anak. sehingga efektivitas dari orang tua akan menjadi terhambat. Sebagian besar masyarakat Indonesia mengalami masalah pada sistem pencernaan yang akut. Mulai dari diare, heartburn (perut kembung), usus buntu, hingga colitis. Hal ini terjadi karena pola makan masyarakat sudah banyak berubah menjadi pola makan bergaya barat (western food). pola makan dengan menu daging-dagingan dan mengonsumsi produk berbahan dasar susu membuat sistem kerja dari sistem pencernaan menjadi lebih berat dari sebelumnya.

Selain itu, masyarakat Indonesia juga cenderung acapkali meminum sesegera mungkin meminum obat sakit perut yang justru makin memperburuk keadaan ususnya. Menurut Infodatin Kementerian Kesehatan, hampir setiap hari jumlah penderita penyakit ringan seperti demam, batuk, flu dan sakit tenggorokan pada anak-anak terus meningkat. Hal ini dapat dilihat dari data rumah sakit rujukan nasional (RSCM), dalam satu tahun (Oktober 2003 hingga Oktober 2004) jumlah pasien anak-anak penderita penyakit ringan berjumlah 18-20 jiwa dari 3289 anak. Hal ini menunjukkan tinggi nya tingkat penyakit ringan yang di derita oleh anak-anak yang ada di Indonesia. Sehingga diperlukan penangganan herbal dari tanaman obat yang mudah untuk 
dinikmati oleh anak-anak dan mengandung antibakteri alami.

Tidak semua nutrisi makanan dapat diserap dengan baik di dalam dinding usus ini. Makanan yang tidak kaya akan enzim biasanya akan memiliki sisa sampah yang lebih banyak dibandingkan dengan makanan yang mengandung enzim yang cukup. Makanan dengan enzim cukup lebih mudah dicerna dan diserap nutrisinya oleh dinding usus dua belas jari. Oleh sebab itu, dibutuhkan makanan yang berasalah dari buah-buahan untuk memperoleh makanan yang terkandung enzim di dalamnya seperti buah Belimbing (Averrhoa carambola.L).

Belimbing (Averrhoa carambola.L) merupakan salah satu tanaman buah yang ada di Indonesia yang kurang diminati oleh anak-anak dalam mengkonsumsinya, padahal kandungan gizi dari buah Belimbing sangat baik untuk sistem kekebalan tubuh anak terutama dalam mengatasi penyakit ringan yang meyerang tubuh kita. Belimbing (Averrhoa carambola.L) memiliki gesture yang unik menyerupai bintang dan menarik jika dipotong, serta rasanya yang cukup variatif dan sedikit manis terkadang membuat buah ini kurang dijadikan panganan konsumsi oleh masyarakat. Umumnya Belimbing dimakan sebagai buah segar dengan gula atau garam. Namun Belimbing dapat juga dimasak sebagai sayuran, acar, dikeringkan, dijadikan selai atau jus. Tetapi, potensi $\mathrm{b}$ buah Belimbinuah Belimbing (Averrhoa carambola.L) belum digali lebih dalam sebagai obat- obatan atau antibiotik. Padahal kandungan vitamin dan nutrisi dari buah Belimbing sangat besar manfaatnya bagi kesehatan. Sehingga peneliti tertarik untuk melakukan penelitian lebih jauh terhadap buah Belimbing (Averrhoa carambola.L).

\section{Tujuan Penelitian}

Tujuan penelitian ini adalah sebagai berikut:

1. Untuk mengetahui bagaimana uji Biokimia yang dilakukan terhadap ekstrak biji buah Belimbing (Averrhoa carambola.L).

2. Untuk mengetahui bagaimana aktivitas antimikroba dari ekstrak biji buah Belimbing (Averrhoa carambola.L).

3. Untuk mengetahui bagaimana proses isolasi dari ekstrak biji buah Belimbing (Averrhoa carambola.L).

\section{Metode Penelitian}

Adapun bahan-bahan yang digunakan dalam penelitian ini adalah biji buah belimbing (Averrhoa carambola L.), MRS agar (Merck). Nutrien broth (Merck), 
Nutrien agar (Himedia, India), antibiotik (amp dan E), larutan Nacl 0,85 \%. HCl. $\mathrm{NaOH}$. Aguadest, glyserol, $\mathrm{NaOH}, \mathrm{HCl}$, aquabidest $\left(\mathrm{ddH}_{2} \mathrm{O}\right)$, alkohol, etanol $70 \%$, spritus, safranin, iodin, kristal violet, kapas, tusuk gigi, media MH (Mueller-Hilton), Bakteri uji Euschericia coli, pepton water.

Peralatan yang digunakan dalam penelitian ini meliputi autoclave, laminar flow, petridish, botol reagent, botol media, tabung reaksi,erlenmeyer $250 \mathrm{ml}$, jarum ose, pipet tetes, bunsen, hot plate. colony counter, vortex, tabung eppendorf 1,5 dan $2 \mathrm{ml}$, spatula, oven, desikator, shaker, kertas saring, timbangan analitik, kertas label, kertas wrap, botol sampel steril, termometer, $\mathrm{pH}$ universal, kaca arloji, gelas ukur, freezer, inkubator (Fisher), kaca obyek, mikroskop, stopwatch, gunting, pisau steril, tupperwear, kertas aluminium, sarung tangan, pinset

\section{Fermentasi Biji Buah Belimbing} (Averrhoa carambola L.)

Proses fermentasi biji buah Belimbing (Averrhoa carambola L.) dilakukan dengan mengambil satu buah Belimbing (Averrhoa carambola L.) yang sudah matang kemudian di kupas dan diletakkan ke dalam daun Pisang yang telah dibersihkan dengan alkohol dan dipanaskan dengan bunsen lalu ditutup rapat-rapat, kemudian dimasukkan ke dalam tupperwear yang telah dilubangi dan didiamkan selama 36 jam dan 48 jam pada suhu kamar.

2. Isolasi Biji Buah Belimbing (Averrhoa carambola L.)

Hasil fermentasi selama 36 jam dan 48 jam diambil dan dilakukan proses isolasi. Isolasi dilakukan dengan cara pengenceran. Dimana dalam proses pengenceran tersebut sebanyak 1 gram biji buah Belimbing (Averrhoa carambola L.) hasil fermentasi dimasukkan ke dalam tabung reaksi yang berisi $9 \mathrm{ml}$ Nutrient Broth cair. Perlakuan ini dilakukan sama untuk masing-masing sampel yang 36 jam dan 48 jam. Selanjutnya diinkubasi pada suhu $37^{\circ} \mathrm{C}$ selama 24 jam.

Setelah diinkubasi dilakukan pengenceran bertingkat dengan menggunakan pepton water. Sebanyak 0,9 $\mathrm{ml}$ pepton water masing-masing dimasukkan ke dalam 7 buah microtube, selanjutnya satu buah microtube tersebut di vortex selama 30 detik lalu diambil 0,1 ml dan dimasukkan ke dalam microtube berikutnya. Perlakuan ini terus dilakukan sampai microtube terakhir. Setelah itu, microtube yang terakhir (ke-7) diambil $0,1 \mathrm{ml}$ dan dilakukan penanaman pada media padat. Media padat yang dibuat dari 2 gram Nutrient Agar dengan 0,8 gram Nutrient Broth ke dalam $100 \mathrm{ml}$ akuades. 
Selanjutnya diratakan dengan menggunakan dirglassky dan diinkubasi pada suhu $37^{\circ} \mathrm{C}$ selama 24 jam.

\section{Identifikasi Morfologi Biji Buah} Belimbing (Averrhoa carambola L.)

Diambil satu ose bakteri lalu diletakkan diatas kaca obyek, dilebarkan dan dilakukan fiksasi bakterinya. Selanjutnya dituangkan kristal violet sebanyak 3-5 tetes selama 5 menit. Lalu dicuci dengan menggunakan air yang mengalir. Lalu ditambahkan lugol dan didiamkan selama 45-60 detik kemudian cuci lagi dengan air mengalir. Selanjutnya celupkan ke dalam bejana yang berisi aseton alkohol sambil digoyang-goyangkan selama 30 detik kemudian dicuci lagi dengan air mengalir, kemudian warnai dengan safranin sebanyak 2-3 tetes selama 1-2 menit dan dicuci dengan air yang mengalir lalu dikeringkan. Kemudian lihat bentuk morfologi bakteri dengan menggunakan mikroskop perbesaran $40 X$.

\section{Uji Resistensi Terhadap Asam}

Pengujian resistensi terhadap asam ini dilakukan pada beberapa variasi pH MRS Broth yaitu pH $2: 3: 4: 5:$ dan 6 . Diinkubasi overnight pada suhu $37^{\circ} \mathrm{C}$. Kultur yang terbentuk kemudian disentrifuse dengan kecepatan $6000 \mathrm{rpm}$ selama 10 menit.

\section{Uji Aktivitas Antimikroba}

Pengujian aktivitas bakteri patogen dilakukan dengan menggunakan kontrol dari antibiotik seperti amp dan E. pada bakteri sampel yang diperoleh. Ditumbuhkan isolat bakteri di tumbuhkan pada media Nutrien agar kemudian di buat sumur agar untuk antibiotik pada masing masing sisi yang ada dalam petridish. Selanjutnya, diinkubasi overnight pada suhu $37^{\circ} \mathrm{C}$ selama 24 jam. Amati zona bening yang terbentuk dan catat hasilnya.

\section{Hasil dan Pembahasan}

Buah belimbing merupakan salah satu buah eksotis yang kaya manfaat. Sekitar 100 gram buah belimbing, menyediakan 31 kalori yang jauh lebih rendah daripada untuk buah-buahan tropis populer lainnya. Selain itu, sejumlah nutrisi penting, antioksidan, dan vitamin mengandung sejumlah manfaat belimbing untuk kesehatan. Fermentasi adalah adalah suatu proses pengubahan senyawa organik (karbohidrat) menjadi alkohol dan karbondioksida atau asam asam amino organik dengan menggunakan bantuan dari mikroorganisme seperti bakteri, jamur dan ragi atau kombinasi dari ketiganya dengan kondisi anaerobik (tanpa memerlukan oksigen). Manfaat dari 
fermentasi ini adalah proses pengubahan karbohidrat yang berlangsung di dalamnya menjadi asam organik, senyawa organik yang dihasilkan mampu mengawetkan makanan sehingga lebih tahan lama.

Fermentasi asam laktat merupakan proses fermentasi yang menghasilkan Asam Laktat. Bakteri asam laktat dapat mengubah gula menjadi asam laktat yang menyebabkan penurunan $\mathrm{pH}$ dan menciptakan suasana asam yang dapat menghambat pertumbuhan mikroba lainnya (Joddi, 2007). Pada hewan tingkat tinggi dan manusia, asam laktat sebagai produk sampingan yang berdampak pada napas yang tersengal-sengal dan pegalpegal di sekujur tubuh. Jumlah energi asam laktat yang dihasilkan sebesar 2 ATP, dengan reaksi kimia sederhananya adalah $2 \mathrm{CH}_{3} \mathrm{CCOCOOH} \rightarrow 2 \mathrm{CH}_{3} \mathrm{CHOHCOOH}+$ $47 \mathrm{kkal}$.

1. Fermentasi asam laktat yaitu fermentasi dimana hasil akhirnya adalah asam laktat. Dimana peristiwa ini dapat terjadi di otot dalam kondisi anaerob.

Reaksinya:

$$
\mathrm{C}_{6} \mathrm{H}_{12} \mathrm{O}_{6} \stackrel{\text { Enzim }}{\rightarrow} 2 \mathrm{C}_{2} \mathrm{H}_{5} \mathrm{OCOOH}+\text { Energi }
$$

Prosesnya :

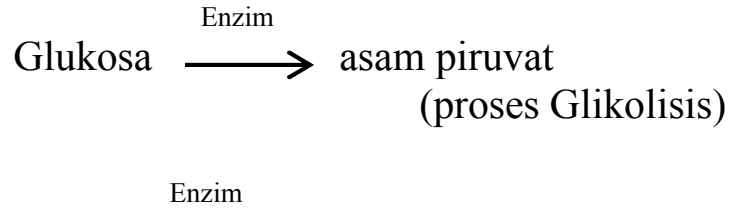

$\mathrm{C}_{6} \mathrm{H}_{12} \mathrm{O}_{6} \rightarrow 2 \mathrm{C}_{2} \mathrm{H}_{3} \mathrm{OCOOH}+$ Energi

Pada respirasi $\mathrm{O}_{2}$ bebas merupakan satusatunya akseptor hidrogen $\mathrm{CO}_{2}$ yang dihasilkan merupakan hasil akhir dari oksidasi, sehingga di dalam respirasi paling banyak dihasilkan energi.

2. Dehidrogenasi asam piruvat akan terbentuk asam laktat piruvat dehydrogenase

$2 \mathrm{C}_{2} \mathrm{H}_{3} \mathrm{OCOOH}+2 \mathrm{NADH}_{2}$

$2 \mathrm{C}_{2} \mathrm{H}_{5} \mathrm{OCOOH}+2$ NAD Energi yang terbentak dari glikolisis hingga terbentuk asam laktat : 8 ATP $-2 \mathrm{NADH}_{2}=8-2(3$ ATP $)=2$ ATP

Dehidrogenase mengkatalisis oksidasi molekul substrat dengan pengurangan hidrogen (dehidrogenase), misalnya oksidasi substrat organik alkohol menjadi asetaldehid atau substrat anorganik hidrogen sulfida menjadi sulfur. Enzim oksidase mengkatalisis pemindahan hidrogen langsung ke oksigen atau penggabungan oksigen pada substrat secara langsung.

Hasil fermentasi selama 36 jam dan 48 jam diambil dan isolasi dengan cara pengenceran. Asam-asam organik dari produk fermentasi merupakan hidrolisis asam lemak dan juga sebagai hasil aktivitas bakteri (Nurmalinda, 2013) Dalam proses 
pengenceran tersebut sebanyak 1 gram biji buah Belimbing (Averrhoa carambola L.) hasil fermentasi dimasukkan ke dalam tabung reaksi yang berisi $9 \mathrm{ml}$ Nutrient Broth cair. Perlakuan ini dilakukan sama untuk masing-masing sampel yang 36 jam dan 48 jam. Selanjutnya diinkubasi pada suhu $37^{\circ} \mathrm{C}$ selama 24 jam. Hal ini dilakukan bertujuan untuk memperkaya jumalah bakteri yang akan tumbuh di dalam media.

Bahan dan peralatan yang dipergunakan dalam penelitian ini sebelumnya, harus dalam keadaan steril artinya pada bahan atau peralatan tersebut tidak didapatkan mikroba lain yang tidak diharapkan, baikyang akan menganggu atau merusak media ataupun meganggu kehidupa dan proses yang sedang berlangsung. Sterilisasi yang dilakukan dengan pemanasan dan penggunaan desinfektan, larutan alkohol.

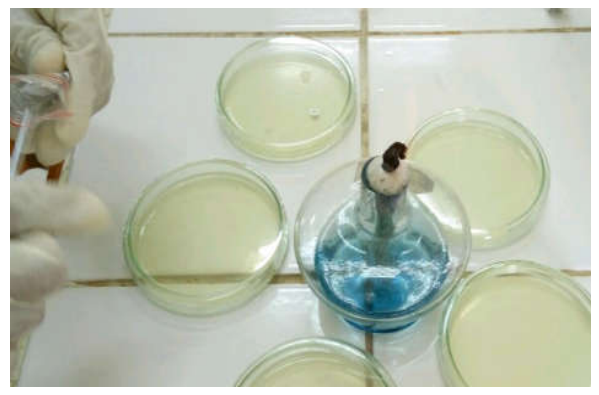

Gambar 1. Pengerjaan yang dilakukan dengan steril

Dari Gambar 1 diatas, untuk pertumbuhan dan perkembangan mikroba, diperlukan substrat berupa media. Sedangkan media itu sendiri sebelum dipergunakan harus dalam keadaan steril, artinya tidak ditumbuhi oleh mikroba lain yang tidak diharapkan.Susunan bahan, baik berbentuk baha alami atau bahan buatan (berbentuk senyawa kimia baik organik ataupun anorganik) yang dipergunakan untuk pertumbuhan dan perkembangan mikroba. Dalam penelitian ini medium yang digunakan adalah medium padat dan medium cair yaitu Nutrient broth dan Nutrien agar.

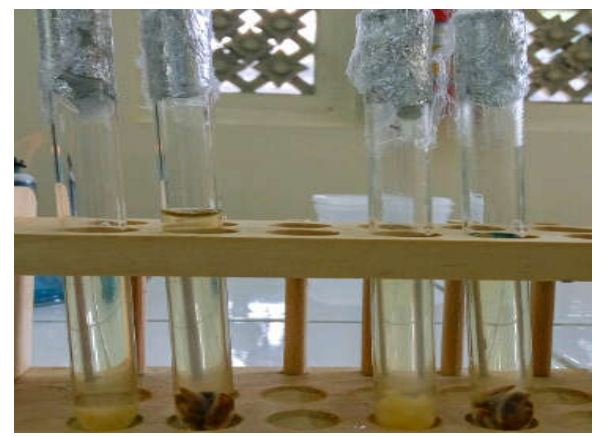

Gambar 2. Isolasi Biji Buah Belimbing

Agar mikroba dapat tumbuh dan berkembang dengan baik di dalam media seperti pada Gambar 2 diatas, diperlukan persyaratan sebagai berikut:

1. Di dalam media harus terkandung semua unsur hara yang diperlukan untuk pertumbuhan dan perkembangan.

2. Media harus mempunyai tekanan osmotik, tegangan permukaan dan $\mathrm{pH}$ yang sesuai dengan kebutuhan mikroba. 
3. Media harus dalam keadaan steril, artinya sebelum ditanami mikroba yang dimaksud tidak ditumbuhi oleh mikroba lain yang tidak diharapkan (Suwiria, 2011)

Proses pertumbuhan mikroba di dalam media pertumbuhan populasi mikroba merupakan penggambaran jumlah atau massa sel yang terjadi pada saat tertentu. Sehingga di dapatkan nilai konsentrasi sel sesuai dengan jumlah sel per unit volume, sedangkan kerapatan sel adalah jumlah materi per unit volume.pertumbuhan populasi mikroba ini terjadi karena adanya pertumbuhan individu. Pertumbuhan individu diartikan sebagai adanya penambahan volume sel serta bagian-bagian lainnya dan diartikan pula sebagai penambahan kuantitas isi dan kandungan di dalam selnya. Misal satu sel menjadi dua, dan dua menjadi empat, empat menjadi delapan dan seterusnya. Kultur biakan dari biji buah belimbing saat diinkubasi selama 24 jam mengalami beberapa fase pertumbuhan bakteri yang terdapat pada kurva pertumbuhan bakteri.

Setelah diinkubasi, dilakukan pengenceran bertingkat dengan menggunakan pepton water. Sebanyak 0,9 $\mathrm{mL}$ pepton water masing-masing dimasukkan ke dalam 7 buah microtube, selanjutnya satu buah microtube tersebut di vortex selama 30 detik lalu diambil $0,1 \mathrm{~mL}$ dan dimasukkan ke dalam microtube berikutnya. Perlakuan ini terus dilakukan sampai microtube terakhir. Setelah itu, microtube yang terakhir (ke-7) diambil 0,1 $\mathrm{mL}$ dan serusnya sampai mencapai konsentrasi larutan terendah sesuai dengan konsentrasi larutan awal. Dengan konsentrasi terendah, maka besar kemungkinan pertumbuhan mikroba pada media akan jarang (tunggal) dan dapat dihitung.

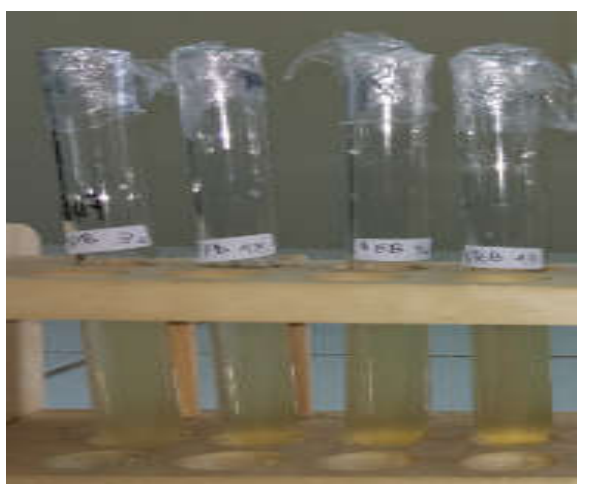

Gambar 3. Proses pengenceran Sampel

Setelah dilakukan pengenceran seperti Gambar 3 diatas, kemudian diambil $0,1 \mathrm{~mL}$ dilakukan penanaman pada media padat. Media padat dibuat dari 2 gram nutrient agar dengan 0,8 gram nutrient broth ke dalam $100 \mathrm{~mL}$ akuades. Selanjutnya diratakan dengan menggunakan dirglassky dan diinkubasi pada suhu $37^{\circ} \mathrm{C}$ selama 24 jam. Pertumbuhan koloni yang kemudian 
timbul pada tiap-tiap petridish, dihitung. Karena untuk setiap koloni yang tumbuh dianggap berasal dari satu sel, maka tiap koloni dianggap mewakili jumlah sel. Dalam cara penghitungan ini harus diperhitungkan kerapatan pertumbuhan koloni, karena kalau pertumbuhan terlalu rapat, biasanya sulit untuk dihitung jumlahnya. Satu koloni dapat berasal dari satu sel atau beberapa sel, tergantung dari tingkat penyebaran atau kemurnian kultur. Goresan dan pembiakan yang diulang beberapa kali terhadap satu koloni yang tumbuh terpisah pada agar cawan dpat menghasilkan koloni yang berasal dari satu sel (Dinata, 2011)

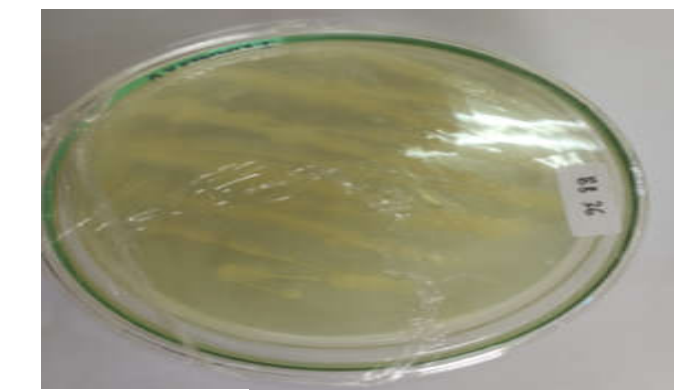

\section{Gambar 4.Bentuk Morfologi \\ Bakteri dari Biji Buah \\ Belimbing}

Dari Gambar 4 diatas, seleksi mikroba dapat dilakukan pada agar cawan, yaitu dengan cara menyebarkan suspensi mikroba pada agar cawan dengan indikator tertentu. Sebagai contoh untuk menyeleksi mikroba yang memproduksi asam organik atau asam amino dari berbagai sumber karbon, dapat dideteksi dengan memberikan pewarna yang menunjukkan $\mathrm{pH}$, seperti penambahan merah netral atau bromthimol blue ke dalam nutrient, produksi komponenkomponen tersebut dapat dilihat dengan melihat perubahan warna dari zat warna pada koloni yang tumbuh, menjadi warna tertentu yang menunjukkan reaksi asam atau basa.

Cara lainnya untuk mendeteksi mikroba pembentuk asam organik adalah dengan menambahkan kalsium karbonat ke dalam medium, dimana produksi asam organik dapat dilihat dengan areal yang bening di sekeliling koloni. Karena selama pertumbuhan mikroba juga memecah komponen anorganik menjadi asam. Dalam proses perhitungan ini harus diperhitungkan kerapatan pertumbuhan koloni, karena kalau pertumbuhan terlalu rapat biasanya sulit untuk dihitungjumlahnya. Sebaliknya, untuk pertumbuhan yang terlalu jarang tidak mewakili jumlah sel yang sebenarnya. Sehingga diperlukan adanya pemilihan cawan yang ditumbuhi koloni yang pling tinggi kemungkinan untuk dihitung serta dapat dianggap mewakili (Faharani, 2009)

Dari hasil perhitungan diperoleh untuk Biji Belimbing 36 (BB 36) dan Biji Belimbing 48 (BB 48) diperoleh jumlah koloni sebesar $110.10^{7} \mathrm{cfu} / \mathrm{mL}$ dan $126 \cdot 10^{7}$ 
$\mathrm{cfu} / \mathrm{mL}$ yang dilakukan pada pengenceran $10^{-7}$. karena pada pengenceran tersebut koloni-koloni bakteri sudah terpisah dengan baik. Dari perhitungan ini menunjukkan bahwa jumlah total koloni ini memenuhi kriteria sebagai probiotik karena menurut World Health Organization (WHO) sebagai pangan probiotik yaitu berada pada jumlah $10^{6}-10^{8} \mathrm{cfu} / \mathrm{ml}$.

Ada keuntungan dan kerugian dari proses perhitungan melalui pengenceran. Adapun keuntungan yang diperoleh dengan cara ini yaitu lebih murah dan mudah tanpa harus menggunakan peralatan yang khusus dan mahal, serta koloni biakan yang tumbuh dapat diteruskan untuk pengamatan ataupun penelitian lebih lanjut. Sedangkan kerugiannya, yaitu sel yang terhitung adalah sel yang masih hidup sedangkan yang sudah mati tidak terhitung.

Dua teknik yang umum digunakan dalam mempersiapkan material atau spesimen untuk pemeriksaan mikroskopis yang umum digunakan yaitu suspensi organisme dalam suatu cairan dan menggunakan lapisan tipis atau olesan spesimen yang dikeringkan, difiksasi dan diwarnai. Dalam penelitian ini teknik yang digunakan untuk melihat morfologi dari bakteri adalah pewarnaan Gram. Dalam proses ini olesan bakteri yang terfiksasi dikenal larutan-larutan kristal violet, larutan iodin, alkohol (sebagai bahan pemucat), dan safranin atau beberapa pewarna tandingan lain yang sesuai. Bakteri yang diwarnai dengan metode Gram ini dibagi menjadi dua kelompok, yaitu Bakteri Gram positif dan Bakteri Gram negatif.

Dari hasil penelitian yang telah dilakukan terhadap sampel BB 36 dan BB 48 setelah dilakukan pewarnaan Gram dan pengamatan secara makroskopis diperoleh hasil bahwa untuk sampel BB 36 diperoleh bentuk morfologi dari bakteri adalah basil atau batang dengan bakteri Gram positif. Sedangkan sampel BB 48 juga sama dengan BB 36 diperoleh bakteri Gram positif dengan bentuk basil atau batang.

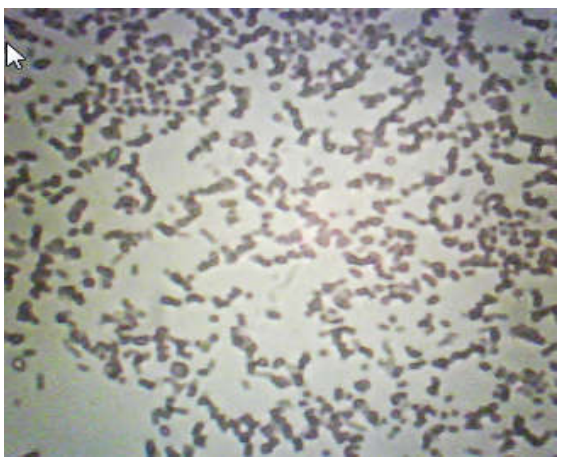

Gambar 5. Bentuk Morfologi Sampel BB 36

Dari Gambar 5 diatas, pewarnaan Gram atau pengecatan terhadap mikroba, banyak dilakukan baikbaik secara langsung bersama (bahan yang ada) ataupun secara 
tidak langsung (melalui biakan murni). ada beberapa tujuan dari proses pewarnaan Gram yang telah dilakukan, yaitu :

1. Mempermudah melihat bentuk jasad renik dari bakteri

2. Memperjelas ukuran dan bentuk jasad renik dari bakteri

3. Melihat struktur luar dan kalau memungkinkan struktur dalam

4. Melihat reaksi jasad terhadap pewarna yang diberikan sehingga sifat-sifat fisik dan kimia yang ada akan dapat diketahui.

Pewarna yang telah digunakan dalam proses pewarnaan Gram umumnya berbentuk senyawa kimia khusus yang akan memberikan reaksi kalau mengenai bagian tubuh jasad renik. Karena pewarna tersebut berbentuk ion yang bermuatan positif atau negatif. Dari penelitian yang telah dilakukan, sel bakteri bermuatan mendekati negatif kalau dalam keadaan pH mendekati netral (Widodo, 2007) Sehingga kalau kita memberikan pewarna yang bermuatan positif hasil pewarnaannya akan jelas. Secara kimia, zat warna yang terjadi dapat berupa senyawa basa dan senyawa asam. Jika warna terletak pada muatan positif maka senyawa tersebut dinamakan zat warna basa. Sebaliknya jika warna terdapat pada ion bermuatan negatif maka senyawa tersebut dinamakan zat warna asam.
Pengujian resistensi terhadap asam ini dilakukan pada beberapa variasi $\mathrm{pH}$ dari nutrien broth yaitu pH $2: 3: 4: 5:$ dan 6 . selanjutnya diinkubasi overnight pada suhu $37^{\circ} \mathrm{C}$. Kultur yang terbentuk kemudian disentrifuse dengan kecepatan $6000 \mathrm{rpm}$ selama 10 menit. Selanjutnya dibandingkan dengan kotrol yang tidak di berikan bakteri. Batas pH untuk pertumbuhan bakteri merupakan suatu gambaran dari batas $\mathrm{pH}$ untuk aktivitas enzim. Untuk tiap bakteri dikenal dengan nlai minimum, optimum dan maksimum.

Laju pertumbuhan dan pembentukan produk bergantung temperatur sehingga biasanya dilakukan pengontrolan temperatur pada kultivasi dan pembentukan produk. Untuk memfasilitasi proses perpindahan panas dari reaktor ke air pendingin digunakan organisme termofilik (A'yuni, 2014) Sedangkan untuk pH sel kultivasi ditentukan oleh $\mathrm{pH}$ optimum untuk reaksi yang diinginkan. $\mathrm{pH}$ yang paling rendah diinginkan untuk menekan infeksi oleh mikroba lain[4]. Kedua buah sampel yaitu BB 36 dan BB 48 yang ditumbuhkan di dalam media nutrient broth dengan variasi $\mathrm{pH}$ antara 2.0-6.0 diperoleh hasil sebagai berikut: 
Tabel 1. Uji Resistensi Terhadap Asam

\begin{tabular}{c|ll}
\hline \multirow{2}{*}{ pH } & \multicolumn{2}{c}{ Sampel } \\
\cline { 2 - 3 } & \multicolumn{1}{|c}{ BB 36 } & \multicolumn{1}{c}{ BB 48 } \\
\hline 2.0 & keruh & keruh \\
3.0 & keruh & keruh \\
4.0 & Sangat keruh & Sangat keruh \\
5.0 & keruh & Sangat keruh \\
6.0 & Sangat keruh & Sangat keruh \\
\hline \multicolumn{3}{c}{ Dari Tabel 1 diatas, diperoleh hasil }
\end{tabular}

uji resistensi terhadap asam dari mikroba pada sampel BB 36 dan BB 48. Pada sampel BB 36 uji resistensi terhadap asam untuk $\mathrm{pH}$ 4.0 dan 6.0 terlihat bahwa mikroba dapat survive dan berkembang dengan baik pada $\mathrm{pH}$ tersebut jika dibandingkan dengan $\mathrm{pH}$ 2.0, 3.0 dan 5.0. hal ini disebabkan karena tidak semua mikroba mampu untuk hidup pada kondisi asam sehingga diperlukan mikroba yang benar-benar mampu untuk hidup pada suasana asam (Gambar 6). Tetapi, secara keseluruhan mikroba pada sampel BB 36 ini memiliki kemampuan yang cukup untuk hidup pada sistem pencernaan.

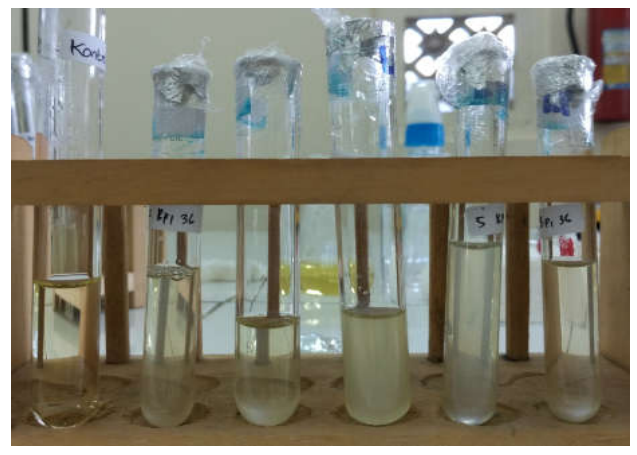

Gambar 6. Uji Resistensi Terhadap Asam
Untuk sampel BB 36 yang telah dilakukan uji ternyata sampel memiliki kemampuan yang cukup baik untuk hidup di dalam sistem pencernaan manusia. Karena pada pH 2.0 mikroba masih mampu untuk hidup dan berkembang biak seperti yang terlihat pada Gambar 7 dibawah ini.

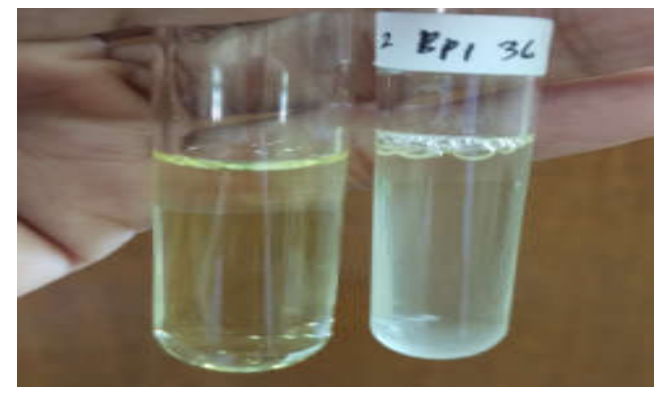

Gambar 7. Sampel BB 36 pH 2.0

Sedangkan Untuk sampel BB 48 yang telah dilakukan uji ternyata sampel memiliki kemampuan yang baik untuk hidup di dalam sistem pencernaan manusia. Karena pada pH 2.0 (Gambar 8) mikroba mampu untuk hidup dan berkembang biak dengan baik. trlihat dari bentuk media yang memiliki kekeruhan sangat keruh dibandingkan dengan kontrol yang digunakan.

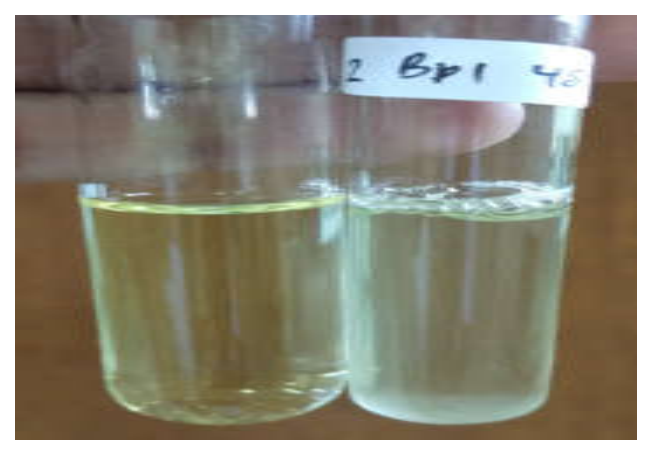

Gambar 8. Sampel BB 48 pH 2.0 
Pengujian aktivitas antimikroba dilakukan terhadap bakteri patogen dengan menggunakan kontrol dari antibiotik seperti amp dan E. pada bakteri sampel yang diperoleh. Ditumbuhkan isolat bakteri di tumbuhkan pada media Nutrien agar kemudian di buat sumur agar untuk antibiotik pada masing masing sisi yang ada dalam petridish. Selanjutnya, diinkubasi overnight pada suhu $37^{0} \mathrm{C}$ selama 24 jam. Bakteri patogen yang digunakan dalam uji aktivitas antimikroba ini yaitu bakteri patogen Euscherichia coli.

antimikroba adalah bahan yang dapat membunuh atau menghambat aktivitas mikroorganisme dengan bermacam-macam cara. Senyawa antimikroba terdiri atas beberapa kelompok berdasarkan mekanisme daya kerjanya atau tujuan penggunaannya. Bahan antimikroba dapat secara fisik atau kimia dan berdasarkan peruntukannya dapat berupa desinfektan, antiseptik, sterilizer, sanitizer dan sebagainya.

Dari penelitian diatas diperoleh hasil uji aktivitas antimikroba untuk sampel BB 36 dan BB 48 yang dilakukan dengan menggunakan medium spesifik untuk uji aktivitas antimikroba yaitu medium $\mathrm{MH}$ (Mueller-Hilton) dan diperoleh hasil sebagai berikut:
Tabel 2. Hasil Uji Aktivitas Antimikroba

\begin{tabular}{l|lll}
\hline Sampel & \multicolumn{3}{|c}{ Hari (mm) } \\
\cline { 2 - 4 } & $\mathbf{1}$ & $\mathbf{2}$ & $\mathbf{3}$ \\
\hline BB 36 & 12 & 14 & 16 \\
BB 48 & 10 & 12 & 14 \\
E & 12 & 14 & 15 \\
Amp & 9 & 11 & 12 \\
\hline
\end{tabular}

Dari Tabel 2, hasil uji aktivitas diatas terlihat bahwa sampel BB 36 memiliki kemampuan aktivitas antimikroba yang cukup baik jika dibandingkan dengan sampel dan antibiotik yang lain. Karena BB 36 memiliki zona bening yang lebih luas yaitu pada hari pertama sampai ketiga terus meningkat yaitu sebesar $12 \mathrm{~mm}, 14 \mathrm{~mm}$ dan $16 \mathrm{~mm}$. Sedangkan sampel BB 48 memiliki zona bening yang cukup baik jika dibandingkan dengan antibiotik ampisilin yaitu sebesar $10 \mathrm{~mm}, 12 \mathrm{~mm}$ dan $14 \mathrm{~mm}$. Tetapi, sampel BB 48 kemampuan antimikrobanya masih dibawah antibiotik eritromisin seperti yang terlihat pada Gambar 9 di bawah ini.

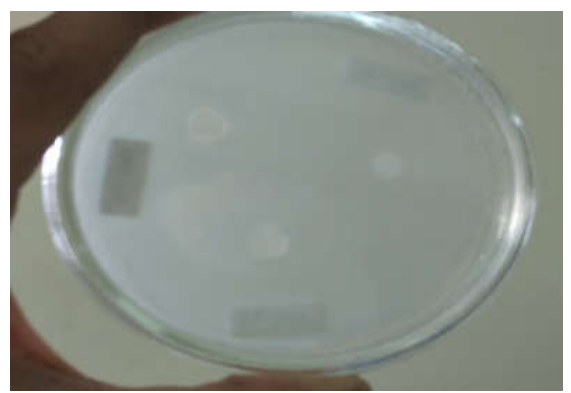

Gambar 9.Uji Aktivitas Antimikroba 


\section{Kesimpulan}

Berdasarkan penelitian yang telah dilakukan, maka dapat disimpulkan bahwa:

1. Sampel ekstrak biji buah Belimbing (Averrhoa carambola.L) yaitu BB 36 dan BB 48 memiliki jumlah koloni yaitu 110 . $10^{7} \mathrm{cfu} / \mathrm{ml}$ dan $126 \cdot 10^{7} \mathrm{cfu} / \mathrm{ml}$. Sehingga dapat digunakan sebagai bahan pangan untuk probiotik.

2. Sampel ekstrak biji buah Belimbing (Averrhoa carambola.L) untuk sampel BB 36 dan BB 48 memiliki bentuk morfologi seperti basil (batang) dan merupakan jenis bakteri Gram positif.

3. Sampel ekstrak biji buah Belimbing (Averrhoa carambola.L) untuk sampel BB 36 dan BB 48 memiliki resistensi terhadap asam yang cukup baik karena dapat hidup pada pH 2.0 - 6.0.

4. Sampel ekstrak biji buah Belimbing (Averrhoa carambola.L) untuk sampel BB 36 memiliki zona bening yang lebih luas yaitu pada hari pertama sampai ketiga terus meningkat yaitu sebesar $12 \mathrm{~mm}, 14$ $\mathrm{mm}$ dan $16 \mathrm{~mm}$. Sedangkan sampel BB 48 memiliki zona bening yang cukup baik jika dibandingkan dengan antibiotik ampisilin yaitu sebesar $10 \mathrm{~mm}, 12 \mathrm{~mm}$ dan $14 \mathrm{~mm}$.

\section{Ucapan Terimakasih}

Terima kasih penulis ucapkan kepada Muhammad Alfan Aulia dan Revita Anggreyani.

\section{Pustaka}

Candra Joddi I, Zahirrudin W, Desniar., 2007, Isolasi dan Karakterisasi Bakteri Asam Laktat Dari Produk Besakam Ikan Bandeng (Chanos chanos), Buletin Teknologi Hasil Perikanan IPB, Vol X (2)

Deden Dinata, I., 2011, Bioteknologi: Pemanfaatan Mikroorganisme Dan Teknologi Bioproses. Jakarta: Buku Kedokteran

Faharani, B.G.R., 2009, Uji Aktivitas Antibakteri Daun Belimbing Wuluh (Averrhoa bilimbi L) terhadap Bakteri Staphylococcus. Jakarta : UI Press

Lestanto Widodo, U., 2007, Mikrobiologi. Jakarta : Universitas Terbuka

Nurmalinda A, Periadnadi, Nurmiati., 2013, Isolasi dan Karakterisasi Parsial Bakteri Indigenous Pemfermentasi dari Buah Durian (Durio zibethinus Murr.), Jurnal Biologi, Vol 12 No. 2: 210-225

Qurrota A'yuni., 2014. Kandungan Vitamin C dan Organoleptik Selai Jambu Biji Dengan Penambahan Ekstrak Kelopak Bunga Rosella dan Buah Belimbing Wuluh. Surakarta: Universitas Muhammadiyah Surakarta

Unus Suwiria, 2011, Mikrobiologi Dasar, Jakarta: Papas Sinar Sinanti 